Article

\title{
On the Inevitable Bounding of Pluralism in ESE-An Empirical Study of the Swedish Green Flag Initiative
}

\author{
Alexander Hellquist * and Martin Westin \\ Swedish International Centre of Education for Sustainable Development, Uppsala University, 75236 Uppsala, \\ Sweden; martin.westin@swedesd.uu.se \\ * Correspondence: alexander.hellquist@swedesd.uu.se; Tel.: +46-734-606590
}

Received: 9 March 2019; Accepted: 3 April 2019; Published: 5 April 2019

\begin{abstract}
This paper explores potential tensions in transformative learning and environmental and sustainability education (ESE) between, on the one hand, pluralistic approaches, and, on the other hand, promotion of societal change to address urgent issues. We stipulate that design of ESE inevitably contributes to a bounding of the plurality of facts and values that are acknowledged in a given learning process. Based on a frame analysis of the Swedish Green Flag initiative, we argue that such bounding by design is a key aspect of how ESE practitioners handle tensions between pluralism and urgency, either consciously or unconsciously. Given its inevitability and importance, we assert that bounding by design is insufficiently theorized in ESE literature, which might partly explain that practitioners perceive pluralistic ideals as challenging. In the empirics, we discern three justifications for bounding by design: (i) certain facts or degree of scientific consensus; (ii) objectives decided by elected bodies; and (iii) decisions taken by student and teacher representatives. We point to the theory of libertarian paternalism and a typology of democratic legitimacy as conceptual tools that can guide further scrutiny of pluralistic ESE and support practitioners in undertaking conscious and transparent bounding by design.
\end{abstract}

Keywords: environmental and sustainability education; transformative learning; education for sustainable development; environmental education; pluralism; libertarian paternalism; legitimacy

\section{Introduction}

A central thought figure in research and policy related to environmental and sustainability education (ESE) is the connection between pluralistic means and sustainability ends. Several premises underpin this thought figure, including the complexity and uncertainty of sustainability issues, adherence to certain democratic values and the potential for learning, agency and an increased concern for common rather than individual goods by involvement of multiple perspectives.

Frequently, sustainability issues are not only characterized as complex and uncertain, but also as grave and urgent, therefore demanding radical societal changes as well as pluralistic and participatory approaches. This combination of ideas is present in the discourse on transformative learning related to sustainability, the focus area of this special issue. As an example, Lotz-Sisitka et al. call for higher education that promotes "whole system re-design", including re-thinking of "the very foundations of what we currently do" and "a paradigm shift and a transition towards doing better things differently (transformation) rather than doing what we do better (optimization)" [1] (p. 1), as well as pedagogies that value "disruptive competences" (p. 5). In the same paper, the authors assert that "The transformative, transgressive forms of learning described all require engaged forms of pedagogy that involve multi-voiced engagement with multiple actors" (p. 6).

The combination of ideas points to potential tensions. Stipulating urgency and graveness as defining properties of a given sustainability issue might compromise pluralism by downplaying arguments for status quo or slower reform. Conversely, acknowledgement of a wide range of 
actors and arguments might compromise swift and radical societal transformations towards specific sustainability objectives.

Such potential tensions are no doubt familiar to every ESE scholar, as they lie at the core of longstanding debates within the field. The discussions can be traced back at least to when Lucas outlined how environmental education can be in, about or for the environment ([2]; see also [3-5]). Wals describe the tensions in the following way:

"On the one hand there is a deep concern about the state of the planet and a sense of urgency that demands a break with existing non-sustainable systems, lifestyles, and routines, while on the other there is a conviction that it is wrong to persuade, influence, or even educate people towards pre- and expert-determined ways of thinking and acting." [6] (p. 150)

Along the same lines, Lambrechts et al. assert that "the urgency of wicked problems does not allow for relativism, and the unpredictability of it does not allow paternalistic and indoctrination approaches." [7] (p. 11).

The tensions are acknowledged also in literature dealing specifically with transformative learning. Moore describes them in terms of ethics:

"Transformative learning is based on the notion of recreating underlying thoughts and assumptions about the systems, structures, and societies that we are a part of. This includes an ethical dimension related to the intentions, methods, and preconceived outcomes suggested by the educator. What are we transforming students into? Are we biased toward certain outcomes for the transformation?" [8] (p. 86)

In this paper, we argue that the bounding of the plurality of facts or values that can potentially be considered in a given ESE context is a key aspect of how the tensions play out and are handled in practice. Drawing on frame theory and a heuristic model, we will explore this argument by analyzing how tensions between pluralism and other prominent norms in ESE are perceived by an important Swedish ESE initiative- the Green Flag, run by the Keep Sweden Tidy Foundation. The Green Flag supports ESE in schools and pre-schools by providing a structure for lectures and activities, and the Keep Sweden Tidy Foundation produces teaching material that is used within the Green Flag structure.

The shift from "traditional" environmental education to education for sustainable development (ESD) in recent decades has been accompanied by an increased emphasis on pluralism and participation in ESE research [9,10]. While there are certainly exceptions [11,12], we assert that, at an overall level, less emphasis has been put on normative teaching approaches that draw on scientific facts and models as objective foundations for value judgements regarding desirable behavior and societal development-what has been called value-rational scientism [13]. By contrast, there is now a substantial literature that explores the rationale and potential of pluralism in ESE from different standpoints. Several contributions link it to pragmatism, in particular to Dewey's transactional learning theory and his work on interlinkages between education and democracy as communicative processes [13-17]. Habermas's theories on communicative action and deliberative democracy have also been influential [18-20]. Both the seminal works on transformative learning [21,22] and contributions on transformative and social learning in the context of ESE [23-25] draw in part on Dewey and Habermas, and stress interaction between a plurality of perspectives as opposed to prescription of certain norms. Contributions on action competence stress the need for pluralism in order to develop capacity to discuss and critically evaluate alternatives [26,27]. In recent years, several studies have explored pluralism in ESE in terms of political struggles between conflicting perspectives striving for hegemony [28-32], drawing on poststructuralist critique formulated by e.g., Mouffe of consensus-oriented deliberation as idealized in Habermas's works [33].

In the literature advocating pluralistic ESE, the necessity of bounding pluralism is often acknowledged, either implicitly or explicitly. In one sense, the necessity is trivial, simply reflecting the fundamental didactic question on what to include or not in education. As stated by Van Poeck and Östman, ESE "necessarily entails the demarcation of what is taken into account and what is not-that 
is, an inevitable struggle over what to care about" [30] (p. 1420). The observation aligns with the widely accepted notion of ESE as unavoidably political and normative $[4,34,35]$.

Still, we argue that literature advocating pluralistic ESE has not sufficiently theorized crucial aspects of how bounding of pluralism is undertaken in practice. While a number of studies explore how pluralism plays out in interactions between teachers and students in Swedish classroom settings [36-39], ESE practitioners' own reasoning on how they bound it when they design learning material, lectures and other activities has evaded close scrutiny in literature known to us, indicating a gap between empirics and theory.

As we elaborate in our discussion, the different strands of literature advocating pluralistic ESE mainly theorize bounding of pluralism as an outcome from within learning processes that adhere to certain standards, emphasizing also the situational judgement of teachers. This aligns with the constructivist foundations of this literature, as well as with certain democratic values. Based on our analysis of written Green Flag material and the reasoning of Green Flag strategists, we however suggest that in ESE practice, pluralism is always bounded in part, either consciously or unconsciously, through design of learning processes and materials-bounding by design. We see that such bounding by design can be used by ESE practitioners to navigate the tension between pluralistic ideals and a desire to steer the attention of learners and teachers towards specific discourses, topics or problem formulations, thereby creating a bias towards certain sustainability issues and directions for societal change.

We will argue that the results of this study call for further theorizing, scrutiny and methodological development in relation to bounding of pluralism by design, both in transformative learning approaches and in ESE in a broader sense. The reluctance towards theorizing bounding by design in literature advocating pluralistic ESE is often implied in expressions of resistance against indoctrination and paternalism $[3,7,23,40]$, as exemplified by the quote from Lambrechts et al. above. However, that bounding of pluralism by design is difficult to avoid in ESE suggests that paternalism is too, at least in formal education settings. In this regard, we will point to the work on libertarian paternalism by Sunstein and Thaler $[41,42]$ as a theorization of non-neutral design that is of relevance to transformative learning and ESE. We will also demonstrate a correspondence between justifications for bounding by design suggested by Green Flag strategists and O'Neill's typology of legitimacy in democratic representation [43]. While additional studies are needed to establish whether this correspondence also holds among ESE practitioners in other contexts, we see that the typology can provide a structure for future critical examinations of pluralistic ESE, as well as conceptual support for more conscious and transparent choices regarding bounding by design.

\section{Materials and Methods}

The empirical case that we have selected for our study-the Green Flag-is a partner in the global Eco Schools program, and has grown successfully since its inception in 1996. As of 2017, it is used in c. 2700 Swedish preschools and schools at primary and secondary levels [44]. According to our experience, the number of school units affiliated with the Green Flag is one of the most common indicators of ESE implementation among Swedish municipalities. The strong position of Green Flag can partly be explained by the relatively few political ESE support initiatives in Sweden during the UN Decade of Education for Sustainable Development (UNDESD) [45,46]. Arguably, it is of interest to study how such a widely spread ESE initiative as the Green Flag perceives and handles the potential tensions associated with pluralistic ESE outlined above.

Our analysis draws on frame theory, which assumes that language shapes practitioners' view of the reality and thus the way they act $[47,48]$. Following Schön and Rein, we define frames as the "underlying structures of belief, perception and appreciation" [47] (p.23) that informs practitioners understanding. Several studies of frames have shown that people's sense making may be messy and ambiguous rather than linear and straightforward. Thus, it is possible that the same individual draws on several internally inconsistent frames that shape their thinking and actions in complex and unpredictable ways [49]. 
We have applied our analysis to transcriptions of semi-structured interviews with four Green Flag strategists; to written Green Flag information and promotion material from 1996 to 2017; and to teaching material produced by the Keep Sweden Tidy foundation that is currently used within the Green Flag. We have not considered teaching material produced for the Green Flag by other organizations. The four interviewed strategists have worked or are currently working at the Keep Sweden Tidy Foundation with the Green Flag initiative, as project leaders or as experts involved in the development of the initiative and in the design of lecture outlines and teaching material that is used in Green Flag schools.

As a method to conceptualize the tension between pluralism and other prominent norms in ESE that we sketch above, and to guide our elicitation and analysis of frames present in the empirics, we use a heuristic model (Figure 1) that is inspired by the well-cited model in Jickling and Wals [23]. Our model represents general frames of the societal role of education and of teaching practices that we have identified as prominent in ESE research and policy.

Societal role of education

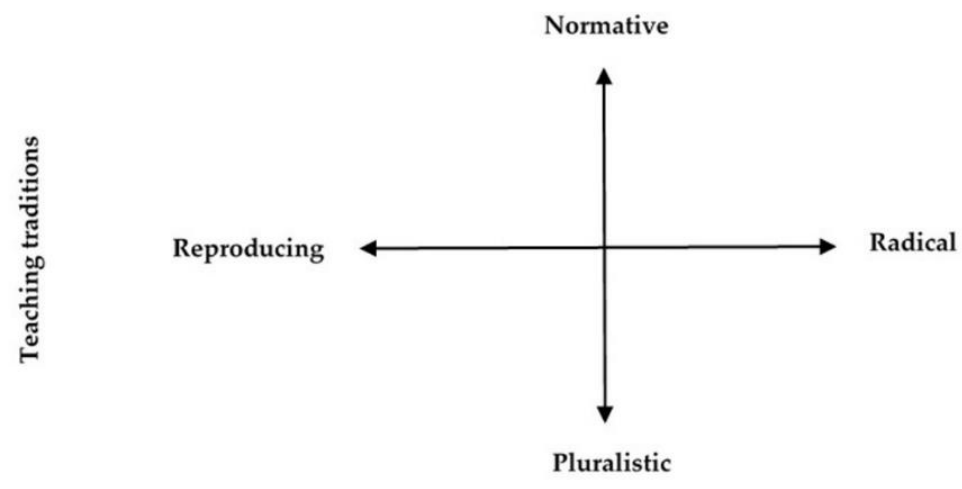

Figure 1. Heuristic model representing general frames of teaching traditions (vertical axis) and of the societal role of education (horizontal axis). Adapted from Jickling and Wals [23].

The vertical axis of our heuristic model represents a scale between two frames that correspond to two "teaching traditions" originally derived through empirical studies of authoritative ESE texts; of syllables; and of teachers' own understanding of their practice [13,50-52]:

1. "Normative", in which ESE is about promotion of objectives, morals and values that are defined before the implementation;

2. "Pluralistic", in which ESE is about enabling democratic discussion based on different perspectives, including opposing fact claims and norms, with the aim of arriving at moral judgements during the implementation.

Important theoretical underpinnings of these two teaching traditions were briefly outlined in our introduction. The space between the endpoints of the axis correspond to increasingly bounded pluralism upwards along the axis, either as the number of acknowledged perspectives decreases or as increasing precedence is given to a certain perspective.

The horizontal axis of the model represents a scale between two general frames of the societal role of education:

1. "Reproducing", i.e. fostering citizens that accept their role in society and comply with prevailing values, norms and institutions. This definition corresponds to what Jickling and Wals call an "authoritative" view of the societal role of educated persons [23], as well as to what e.g., Biesta has conceptualized as the "socializing" function of education [53]. 
2. "Radical", i.e. promoting fundamental change on a societal level by challenging existing norms and institutions. This definition corresponds to radical properties linked to the concept of transformative learning by some ESE scholars [1,54].

The space between the two endpoints of the axis accordingly defines a spectrum between status quo or reform-based change that does not challenge prevailing norms to the left and increasingly radical change to the right.

Compared to the heuristic model in Jickling and Wals [23] (Figure 1, p. 9), our model has been adapted to the analytical purpose of this study by inclusion of separate frames linked to pluralism and radical social change, respectively. This allows us to make explicit and investigate the potential tensions inherent in conceptualizations of transformative learning and pluralism in ESE. By contrast, the model by Jickling and Wals includes a single "Socio-Constructivist/Transformative" "idea about 'education"' (p. 9) that in our interpretation implies both pluralism (the authors refer to Dewey's transactional learning theory and co-creation) and radicalism (expressed as social critique and action orientation).

Apart from obvious tensions involved in combining the frames at opposite ends of the same axis in relation to a specific topic in ESE, tensions between frames from separate axes are also conceivable. The axes are not independent, as the societal role of education influences and is influenced by teaching traditions in terms of pedagogy and didactics. Torbjörnsson describes this connection in the following way:

"[One] question concerns to what extent the purpose of education should be seen as conserving or change-inducing at societal level. No matter how the question is answered, each reply illustrates that teaching has political and moral consequences that are dependent on the teacher's conscious or subconscious didactic choices." [55] (p. 42; translated by us)

Consequently, tension may arise if promotion of radical societal change is combined with pluralistic teaching wide enough to embrace arguments for slow reform or status quo. Conversely, tension may arise between reproduction of certain societal values and pluralistic teaching that embraces arguments against these values. In a corresponding way, potential tensions associated with normative teaching are conceivable, if the logic underlying this teaching tradition is at odds with values that the education system aims to either safeguard through reproduction or establish through societal change.

Two analytical questions that correspond to the two axes in our heuristic model have guided our analysis of the empirics. In the written material, we looked for sections describing:

1. desirable or actual influence from Green Flag activities on a societal level, and

2. correspondence between Green Flag activities and the normative and pluralistic teaching traditions.

The interviews had two stages in common:

1. At the onset of each interview, the respondents were asked to describe their views on (a) desirable or actual influence from Green Flag activities on a societal level; and (b) correspondence between Green Flag activities and the normative and pluralistic teaching traditions. These two points mirror the analytical questions applied to the written material.

2. Then, the respondents were pointed to possible tensions elicited from the written material and the initial stage of the interviews, as interpreted by us. The respondents were asked if they agreed on these possible tensions and, if so, how they are handled, or could be handled, in the Green Flag initiative.

Following frame analysis methodology [56], we have searched for salient information related to the analytical questions in the written material and interview transcriptions, i.e., information that is emphasized and/or persists across different statements and sources. We have interpreted such salient information as articulations of frames. In our analysis below, all quotes have been translated from Swedish to English by us. 


\section{Results}

\subsection{Frames Elicited from Written Green Flag Material}

A key document that outlines the theoretical foundations of the Green Flag is called "Our philosophy-Agency and sustainable development in school" [57] (hereafter, we refer to it as the "Our Philosophy document"). It is an articulation of an ESE research-practice interface, as it identifies principles and findings in Swedish ESE research that Green Flag adheres to, thus providing a backdrop for frames elicited in the other empirics.

In terms of the horizontal axis describing the societal role of education in our heuristic model, the potential for students to become change agents runs through the document as a general theme, as indicated already in the title. Two examples of this are given below:

"It is important to lecture about grave future issues, and pedagogues should not be afraid to make students concerned. Instead, it is about helping young people to handle their worries in a constructive way. [ ... ] In order to sense hope, it is important to feel that it is possible to act and exercise influence, as well as trust in other actors to do something." (p. 3)

"As students grow older it becomes important also to visualize interconnections, and to discuss solutions at a higher level of abstraction than lifestyle and everyday choices. One example is to discuss what happens if we as individuals or groups decrease our consumption of fossil fuels. This might inspire other individuals and groups around the world to do the same. It might also lead to decreasing fossil fuel prices, which might cause others to increase their consumption. Therefore, agreements at higher levels need to be discussed as well, e.g., carbon dioxide fees or cap and share. If not, there is a risk that many students remain at the level of the private sphere in their reasoning about the climate issue." (p. 5)

Societal (not just individual) change is implied here through the focus on agency, along with an orientation towards "solutions" to sustainability issues, some of which are perceived as "grave". It is not explicit how radical the scope of this change is, and the document does not provide outlines of the content of desired change, save for the section on fossil fuels quoted above. Instead, the document cites a more overarching goal in the Swedish national "Curriculum for the compulsory school, preschool class and school-age educare" (hereafter, we refer to this document as "the curriculum"): "each student [...] shows respect and care for both the immediate environment, as well as the environment from a broader perspective" (p. 3).

A few paragraphs in the Our Philosophy document adhere to notions of human rights and certain democratic values:

"Education aiming for agency should have democracy built in to its objectives, means and methods. The education should convey knowledge about basic democratic values, but it should also, in accordance with the Swedish national Curriculum [ .. . ], be implemented through democratic modes of work [ . . ]" (p. 4)

Democracy is a complex and contested concept, and the text does not specify "basic democratic values" or "democratic modes of work" in detail. However, it emphasizes participation, influence, and respect for different opinions. These values are arguably widely accepted and well institutionalized in the Swedish democratic system, at least at the formal level, and in this sense the text implies a strive to reproduce them.

In terms of the vertical axis in our heuristic model, several sections in the Our Philosophy document embrace the pluralistic teaching tradition, as exemplified in the quote below. By contrast, frames that explicitly align with the normative teaching tradition are lacking.

"Environmental issues are increasingly viewed as conflicts of interests among humans, including ecological as well as social and economic sustainability aspects, which makes them 
more political. The task of the school from a pluralistic perspective is to critically examine and analyze both facts and values without providing readymade answers regarding what is a correct choice." (p. 5)

In one instance, the text points to a potential tension between pluralistic teaching and respect for human rights:

"The curriculum states that the school should be open to divergent opinions and encourage that these are articulated. At the same time, it is important not to lose other parts of the value foundation [of the curriculum], such as respect for human rights and that all humans are equal in dignity." (p. 5)

The other analyzed written Green Flag material mostly aligns with the frames that dominate the Our Philosophy document. Statements that imply reproduction of democratic values and pluralistic teaching are salient. In Green Flag information and promotion material, a strive for societal change is mostly outlined in terms of agency, while scope and direction are not explicit. In the analyzed teaching material, there are, however, several activities that correspond to the normative teaching tradition frame in our heuristic model. While these activities do not rule out elements of pluralism in their application, directions for societal change are implied already in their design. To exemplify, two quotes from descriptions of such exercises are given below:

"This escalator shows how waste is managed. It is best if we keep ourselves at the top part of the escalator. Questions to consider: 1. The top step [of the escalator] is about decreasing the amount of waste from the start. How is this done? [ ... ] 5. Why is it important to reuse and recycle when possible?" [58] (p. 3)

"You are citizens of Tuvalu, an island nation in the Pacific Ocean. Your beautiful nation is threatened by climate change. The sea level is rising and threatens to flood the islands, salt water destroys the soil, and the coral reefs outside the coast are affected when the sea becomes warmer and more acid. Within a couple of decades, it might be that you have to abandon your islands." [ ... ] "The students are given the task to write a letter to the leaders of the world to explain what is going on in Tuvalu, the reasons behind this, and what needs to be done to avoid that the islands are flooded." [59] (p. 12)

In summary, our analysis of the written Green Flag material elicits frames that correspond to all the four general frames in our heuristic model. Overall, frames that embrace the pluralistic teaching tradition and reproduction of certain democratic values dominate, along with frames that indicate societal change in the general sense of strengthening agency of students. This overall picture corresponds to the assessment of Swedish ESE policy documents by Olsson and Gericke [39] (p. 38). At the same time, the analyzed teaching material includes activities that align with the normative rather than the pluralistic teaching tradition. As we now turn to our analysis of the interviews, we will focus on how the respondents perceive potential tensions stemming from this combination.

\subsection{Frames Elicited from Interviews with Green Flag Strategists}

As described above, at the onset of the interviews, the respondents were asked to describe their views on the societal role of Green Flag, as well as on how Green Flag activities correspond to the normative and pluralistic teaching traditions. The answers predominantly conformed to the frames elicited from the Our Philosophy document. In terms of the societal role of Green Flag, the respondents emphasized promotion of agency and critical thinking, and strengthening of democratic competencies through student participation and deliberation. In terms of the teaching traditions, they described pluralism as an ideal that has become more important over time, as Green Flag has strived to support schools to meet democratic objectives in the value foundation of the curriculum. This represents a shift of emphasis compared to the 90s and 00s, when Green Flag 
activities revolved more around the environmental impact of Green Flag schools in terms of e.g., energy consumption and waste management.

In a few answers, the respondents elaborate on how they frame Green Flag as a promotor of societal change beyond development of general agency, linking the initiative explicitly to certain sustainability issues. One example is given below:

"So, if we return to your question why we are doing this? Well, we do it because we want to reach out with sustainability issues to children and youth, to achieve a molding effect, to influence the future. [ ... ] So, this is the reason. When it comes to littering, we have worked more or less with it [over time]. We supply pedagogical material about the littering issue. That is our role."

In both the written material and in respondents' outlines of how the pluralistic teaching tradition is promoted by Green Flag there are several descriptions of activities that enable discussions about sets of perspectives that are pre-defined by design. The following quote from a respondent is one example of this:

"The methodology has partly relied on four corner exercises, the hot chair, that sort of things ... [One example is] refrigerators in China. In the early 90's, this seemed like an odd inquiry, but since then there has been a lot of discussion about the enormous increase in material standards in China. 'We don't have a right to decide about refrigerators in China' - that would be one corner [when doing the exercise]. 'We should export environmentally friendly refrigerators to China' would be another corner. 'We should send our old refrigerators to China for reuse' would be another corner. 'We should abolish refrigerators in China' would be another corner. People would stand in different corners, as a basis for discussion. You could say that this is the holistic view of environmental education that has been dominating lately and is expressed through the curriculum in my view - that we should provide students with a capacity to understand sustainable development and then make decisions themselves."

Following the initial questions, the interviewer pointed the respondents to the possible tensions between frames elicited from the written Green Flag material. The interviewer asked the respondents whether they agreed on these tensions, and if so, how they perceive that they play out and can be handled. Below, we quote a few answers that are key to our discussion in the next section.

One respondent describes difficulties in getting the message of pluralism across to teachers in Green Flag schools:

"My impression is that schools and teachers believe that they are more pluralistic than they are. We see this when we ask about the extent of student involvement-they describe this in very different ways ... [ ... ] Sometimes we feel that we nag and nag just by raising the question [of student involvement]... But how it is implemented is a different matter ... Some [teachers] do a lot, they try to collect information about how students think. There is an awareness that this is something good, that it strengthens the education. But on the other hand, in some sense they [the teachers] are forced to think along those lines. Each teacher solves the issue in their own way. [ ... ] It is a process I think, speaking of development, to abandon a view that students are empty sheets who you are supposed to teach values that you believe in. There is a great span in the pluralistic thinking; in which perspectives you include. We have not reached as far as you would think. There is plenty of valuing in schools, regarding how students express themselves. [ ... ] The question is to what extent this can be taken out. Perhaps it is better to refer to the curriculum [as a basis for valuing how students express themselves]. Maybe that is more realistic. Then it is at least clear where the valuing comes from, so that you can relate to it."

"When it comes to sustainability issues—-then things come to a head, there are certain things that are not feasible. I believe that this is very difficult for teachers ... [ ... ] you notice that 
they have an idea about what a good society looks like, and what sound values are. You cannot desire more cars. It is probably difficult for teachers to allow conversations among students that ends with a conclusion that grown-ups have not approved of as sustainable. [... ] We want to work with this, but at the same time, you cannot pretend that students can have a say on everything that we work with, that is not feasible. Instead, you have to follow a curriculum where there are certain objectives that teachers should strive for. So instead, we have called on teachers to examine what students see and think and wonder about and are interested in; we have tried to stress how important it is to pose open questions and take the preunderstanding of students as a starting point; and other things that I believe enable pluralistic approaches. [ ... ] In our trainings [for teachers], we have tried to help by talking about sustainability issues as complex questions without right or wrong answers. The teachers are like 'can you please tell us what is correct?'. Then I can only tell them that there are pros and cons with everything, and that you need to support the students in acknowledging that it is a complex world and in using information at hand to reach decisions. But the teachers might not be there themselves, they ask 'how should one do, how should one think?'. I believe that our approach contributes to pluralistic thinking; there are no truths [ ... ] and that teachers do not have to know, because it is possible to explore together with students. One day, evidence says that it is better to buy an organic apple, but the next day ..."

These quotes express an ambiguity. On the one hand, the respondent asserts that some things are difficult to align with sustainability-"there are certain things that are not feasible", such as "more cars". On the other hand, the respondent acknowledges the difficulties in defining what is right or wrong in terms of sustainability-"there are no truths". While the two statements are not logically incommensurable, the reported difficulties in embracing the pluralistic teaching tradition among teachers seem linked to a tension between them. As a possible strategy to address the tension, the respondent points to the curriculum objectives as a justification for bounding pluralism by establishing certain scope and content. In other respondents' answers, we find suggestions along the same lines:

"The value foundation [of the curriculum] serves a purpose; that students should gain certain insights and understand certain things and become good citizens and so on, and that is decided by the government and the parliament. [ ... ] In Canada, at least in some states, fact-based knowledge is the realm of the school, while norms, values and attitudes are the task of the church and the hockey club. [ ... ] It is a completely different view of education. It is an interesting question-to what extent should the state govern [education]?"

"I believe that this is a fairly common misconception; people say that it [Green Flag] is only about recycling. If you think so, you have not looked carefully into the tool. Of course, many [schools] work with recycling. The ecological cycle is included in all curricula and courses. It seems that people neglect this issue. If you look at the Sustainable Development Goals, sustainable consumption and production, they address how we handle our resources. This is an incredibly important question. If we handle our resources in a good way, we do not have to produce as much new stuff, you save energy. Littering is an effect of unsustainable consumption; it causes micro-plastics to end up in the ocean. If we had circular use of materials, we would solve many other environmental problems, so it is a key issue. It is possible to discuss it on many levels, also in gymnasium. [People say] it is only about recycling', as if that was an unimportant question. It is an economic issue as well. Some jobs are about mending stuff and renting out stuff, in order to create a circular system. It is very important that you talk about sorting trash in preschool. They [the children] go home and tell their parents, become experts, inspire their parents. Sometimes people talk about it [sustainability] as something very big and complex. Those who try to make it tangible get somewhat downgraded sometimes." 
In our interpretation, the respondent cited in the first quote suggests that the politically mandated value foundation of the curriculum justifies that certain "norms, values and attitudes" are passed on to students, by making a comparison with the Canadian school system. In the second quote, our interpretation is that the reference to curricula and the UN Sustainable Development Goals (SDG's) serves as a justification for stipulating a particular focus area and direction of societal change, in this case recycling and a circular economic system.

When the respondents elaborate on the Green Flag promotes democratic modes of work in terms of student influence, we discern an analogous argument-that curriculum objectives provide boundaries for the degree of participation and influence. One example is given below.

"When we design lectures, things become very tangible. We try to include components of participation, but in a feasible way. [ ... ] Things that are possible to implement. [ ... ] In our surveys, we frequently receive answers on participation saying 'well, sort of'. They [the students] have been given a say, in a way, but maybe they did not realize it. They have been given influence to some extent, but they perhaps anticipated that they could decide the course content. But the frames are set and you need to acknowledge that. [... ] There are course objectives to be met, you are supposed to inspire and coach students to reach the objectives. It is important to use different sorts of working modes. Not only information, but also discussions, questioning and dilemmas-you work in different ways and you participate in the lectures in order to avoid one-way communication all the time. But sometimes, I believe that this [one-way communication] is useful as well. It is a mix."

At the same time, the respondents emphasize that the selection of a sustainability theme to focus on in a Green Flag is made by a local "Green Flag council" of engaged teachers and students. The democratic aspect of this selection can be interpreted as a possible justification for bounding pluralism.

"To me, Green Flag is democracy. The Green Flag council is a foundation. Children and teachers decide together-what to do, what to work with. [... ] The council decides if they want to work with batteries, littering or something else. We work a lot with Agenda 2030 and the SDG's. Now, it is possible to indicate [in the digital reporting system of the Green Flag] which SDG your work is linked to."

In other answers, we discern an additional suggestion for how bounding of pluralism can be justified:

"What are reasonably boundaries to pluralism? After all, there are facts ... Sometimes I feel that you must not forget about the planetary boundaries; they are expressed in the system conditions and so on. Sometimes I feel that the environment is not very prominent in ESD. Other things are important, but it is still the environment and the nature that set limits to what we can do on this globe. It is a basis for me. [ ... ] you have to, sort of, understand that you have to do certain things that might feel like sacrifices or conflict ridden."

"Climate change sceptics are difficult. They are only 2 percent, though ... should you always acknowledge all perspectives, even when they are not relevant? That is not realistic, and for how long are we supposed to do it? I would have understood if they [climate change sceptics] constituted 30 percent against 70, but if it is only 2 percent ... [ . . ] For how long do we include everyone? When have we reached a decision? If you want to bring everyone on board, it takes very long. And it is not certain that people can change."

"Before the ESE conference in Linköping, we were to plan discussion sessions, and one suggestion for a topic was 'how can we move from normative and fact-based to pluralistic education?". But then someone said 'shouldn't we ask how to make them complements?', and that felt liberating. Sometimes it feels like you are absolutely not allowed to talk about fact-based and normative, because everything has to be pluralistic ... It has to be mix, it is 
like ... if you have worked in schools you know that it is needed. I think that it is dangerous to run in only one direction. It is important that it [pluralism] has become acknowledged and of course you should work according to pluralism and see that there are no single right answers. You have to be able to discuss and view things from different perspectives and so on, but you have to be able to give a lecture about climate and carbon dioxide as well, how it actually impacts the climate, it is a precondition."

The quotes point to certain facts or degree of scientific agreement as a basis for bounding pluralism. In the last quote, the respondent asserts that in practice, ESE has to involve a mix of normative and pluralistic teaching. The respondent also refers to the fact-based teaching tradition, which was originally derived alongside the normative and pluralistic teaching traditions [50]. According to this tradition, objective facts related to sustainability can, and should, be separated from normative implications in ESE teaching [13]. Fact-based teaching strives to avoid any influence on the moral stands of students by excluding both promotion of certain values (as in normative teaching) and discussion on competing values (as in pluralistic teaching). Hence, it falls outside the spaces defined by our heuristic model. The idea that it is possible to separate facts from values in ESE has been widely questioned in research $[4,35,60,61]$.

\subsection{Summary of Frame Analysis}

The four general frames in our heuristic model are all present in the empirics, albeit with varying frequency. As already indicated in our comments on the quotes, we discern tensions between some of the elicited frames. More specifically, we see a potential challenge in combining:

1. an endorsement of the pluralistic teaching tradition and a strive to reproduce democratic values related to student participation, influence and open-ended discussion, with

2. promotion of societal change that in some cases goes beyond development of general agency by defining direction and scope, partly through teaching material that enables normative rather than pluralistic teaching.

In the empirics, this tension is discernible as a certain conceptual dissonance between the Our philosophy document and some of the examined Green Flag teaching materials; as ambiguity among respondents regarding the presence of objective foundations for moral judgements on sustainability issues; and as reported uncertainty and hesitation among teachers regarding pluralistic teaching and student participation. The tension can be viewed in light of earlier reports on challenges in implementation of participatory and pluralistic ESE in Swedish schools and preschools [50,55,62-65].

In their reasoning, the respondents indicate several ways of handling the tension. As we read them, they all outline justifications for bounding of pluralism in the design of teaching materials, lectures and activities undertaken by the Green Flag, thereby allowing for elements of normative teaching and promotion of certain societal change. We propose that three generally formulated justifications can be derived from the suggestions:

1. Certain facts or degree of scientific consensus can justify bounding of pluralism by design of ESE, by giving precedence to selected perspectives, downplaying others, or specifying a direction for societal change to be promoted.

2. Objectives decided by elected bodies (e.g., curriculum objectives, SDG's) can justify bounding of pluralism by design of ESE, by defining a content or a direction of societal change to be promoted.

3. Decisions taken jointly by student and teacher representatives can justify bounding of pluralism by design of ESE, by defining a content or a direction of societal change to be promoted.

\section{Discussion}

Our results indicate that literature advocating pluralistic ESE has had a significant influence on how the Green Flag perceives its field of work, not least conceptually, as a majority of elicited 
frames align with the pluralistic teaching tradition frame of our heuristic model. At the same time, the respondents report that pluralistic teaching in schools associated with the Green Flag is challenging, which implies a need for further discussions and theorizing. In our view, the justifications for bounding pluralism derived from the Green Flag empirics point to several avenues for such discussions. Below, we reflect on a few connections between the justifications and the prominent theoretical underpinnings of pluralistic ESE that we identified in our introduction. Then, we will point to linkages between the justifications and the concept of libertarian paternalism, and a typology of legitimate sources of representation that could serve as useful conceptual tools in future research and practice.

The justifications for bounding by design derived from the Green Flag empirics stand in contrast to key messages in the different strands of literature advocating pluralistic ESE. Contributions that draw on Habermas's theories stress how ESE should enable deliberation that adheres to standards of communicative rationality, including acknowledgement of the plurality of relevant perspectives on an issue and exchange of legitimate validity claims, which potentially can create consensus [14,18-20]. Contributions that draw on post-structuralism outline instead how ESE can adhere to principles of difference democracy, which holds that political conflicts cannot be overcome through rational consensus as idealized by Habermas. Instead, they call for pluralism in terms of safeguarding the political contestability of issues discussed in ESE through agonistic debate and a continuous openness to perspectives that challenge hegemonic norms and discourses $[28,37,66]$.

Even though these theories provide limited explicit support for bounding by design, certain elements of agreement with the justifications put forward by the Green Flag strategists are found in texts that discuss their practical application. In relation to difference democracy, some ESE authors take note of Mouffe's assertion that a democracy must rely on a "conflictual consensus" on the values of liberty and equality for all $[16,30]$. These values thus cannot be rejected, although their interpretation is subject to debate. In relation to the justifications, this implies that curriculum objectives of liberty and equality should not be contested in ESE. In terms of our heuristic model, it links to the potential tension between pluralistic teaching and the reproduction of human rights that is indicated in the Green Flag Our philosophy document. Mouffe's assertion can be compared with the view of Kronlid, who, for pedagogical reasons, suggests that students should be allowed to express anti-democratic (but not illegal) arguments in school [67].

Certain support for the justifications is also found in contributions on how Habermas can inform ESE. While acknowledging the different types of validity claims that Habermas outline as fundamental to deliberation, Fritzén and Gustavsson assert that "In order to keep such [deliberative] discussions from being a mere exchange of personal opinions, the arguments should be based on scientifically grounded knowledge" [19] (p. 156). This position can be contrasted with those of scholars who hold that knowledge stemming from positivistic science should not be privileged over other types $[13,68]$.

Also drawing on Habermas, Englund et al. [20] translate the ideal conditions for communicative rationality into less strict characteristics of "deliberative communication" in formal education. For example, Habermas's requirement for inclusivity-" no one who could make a relevant contribution may be prevented from participating" [69] (p. 82)—is modified as "different views are confronted with one another and arguments for these different views are given time and space and are articulated and presented" [20] (p. 38), allowing for a less comprehensive representation of relevant perspectives. In the motivations for relaxing Habermas's requirements in educational settings, Englund et al. draw on Fraser's [70] concept of weak publics:

"deliberative democracy implies in principle (if not in reality) equal citizens, while the participants in deliberative communication in formal educational settings, for example, are teachers and students, that is, individuals with differing knowledge and experience and differences in authority, formal as well as real, deliberating within a 'weak public.'" [20] (p. 34)

The reference to authority and knowledge corresponds to the justifications for bounding pluralism based on curriculum objectives and facts conveyed by teachers. Englund et al. stress the situational 
judgement of teachers when deciding on such deliberation, and on the conditions for it: "Creating $a$ discursive situation in the classroom, and having intuition and knowledge about whether this situation is at hand, are mainly a matter of the teacher's judgement, a matter of phronesis." (p. 39), and "it is the professional teacher who has the crucial role with regard to the direction, possible continuation, and conclusion of deliberative communication." (p. 41)

Literature that advocates pluralistic ESE based on pragmatism and Dewey's transactional theory conceptualize learning as meaning-making that stems from continuous interplay between, on the one hand, learners and their previous experiences, and, on the other hand, their social and physical environment $[7,16,71]$. This process-oriented understanding of learning and the anti-foundational ontology of pragmatism can explain the reluctance to theorize bounding of pluralism by design in this literature. However, Dewey's writings on education do not oppose attempts to undertake such bounding. In "Democracy and education", Dewey discusses different expression of "education as direction" and educational aims [72]. He asserts that "purely external direction is impossible" (p. 30) and that students can only be influenced in terms of re-direction of processes already ongoing, using their environment as a necessary intermediary. Nevertheless, he also explicitly outlines the task of schools to purposefully select material and methods that enter this learning environment, thus implying bounding by design:

"it is the business of the school environment to eliminate, so far as possible, the unworthy features of the existing environment from influence upon mental habitudes. [ ... ] Selection aims not only at simplifying but at weeding out what is undesirable. [ ... ] The school has the duty of omitting such things from the environment which it supplies, and thereby doing what it can to counteract their influence in the ordinary social environment. By selecting the best for its exclusive use, it strives to reinforce the power of this best." (p. 25)

As pointed out by Mougan [73], Dewey rejects that such control of learning environments must be coercive, acknowledging that individuals sometimes chose to go their own way. At the same time, Dewey trusts the human urge to take part in social activities where meaning and common interests emerge in relation to their environment. Mougan argues that there are similarities between Dewey's view and the concept of libertarian paternalism coined by Sunstein and Thaler $[41,42,74]$. Sunstein and Thaler assert that paternalistic influence of societal institutions is difficult to avoid, as "there is no such thing as neutral design" [42] (p. 3), but that certain freedom of choice can still be respected:

"Once it is understood that some organizational decisions are inevitable, that a form of paternalism cannot be avoided, and that the alternatives to paternalism (such as choosing options to make people worse off) are unattractive, we can abandon the less interesting question of whether to be paternalistic or not, and turn to the more constructive question of how to choose among the possible choice-influencing options." [41] (p. 1159)

We agree with Pedwell [75] that the assumptions underlying the views of Dewey on the one hand and those of Sunstein and Thaler on the other diverge in important aspects. In particular, whereas libertarian paternalism implies that behavior can be influenced in predictable, top-down ways without necessarily considering possible needs for wider structural change, Dewey emphasizes that intentional influence cannot be predicted exactly, and that it is necessary to acknowledge how unique individuals with a free will interact with a wider complex and dynamic environment.

Nonetheless, we assert that the concept of libertarian paternalism is a reasonable valid and realistic characterization of how pluralism is often applied in Swedish primary, secondary and pre-school ESE. In the Green Flag empirics, it is evident e.g., in the choices that Green Flag councils make between predetermined sustainability themes, and in learning activities that allow for pluralism within boundaries defined by policy objectives such as the SDG's. In these outlines, it enables what Håkansson et al. call normative deliberation [31], i.e., political deliberation in an overall direction that is defined by design. 
To the extent that such paternalism cannot be avoided in ESE design, ESE literature that ignores it or holds that it should be resisted might not be useful to practitioners. Instead, both its liberal non-coercive elements and its normative biases should be constructively acknowledged. In this regard, we suggest that the justifications for bounding by design can be viewed as examples of the choice-influencing options that Sunstein and Thaler mention in the quote above. As such, they deserve scrutiny in order to, in the words of Wals, "reflect on and expose the, often-times, implicit normativity of education in general and of education for sustainable development in particular" [6] (p. 150). Sunstein emphasizes that "choice architecture should be transparent and subject to public scrutiny" [74] (p. 428), which in our view partly responds to the critique that Pedwell formulates against libertarian paternalism. We argue that in a corresponding way, strategies for bounding of pluralism in ESE should be as conscious and transparent as possible. Here, we see an important reference in Kelly's principles to safeguard against indoctrination through education [76]. These include teacher disclosure, which implies e.g., that "teachers should disclose their view openly and unashamedly" (p. 130). We propose here the addition that teachers engaging should disclose justifications for how they bound pluralism, or, in more general terms, how they chose to handle the tensions between the ideals stipulated by the frames in our heuristic model. This is crucial not least in transformative ESE approaches that strive for radical societal change. While we agree with Englund et al. [20] that teaching is always based partly on situational judgement, and thus can never be described fully in terms of general strategies, the inevitably normative and political aspects of ESE practice must allow for critical examination, which is difficult if teachers' choices are legitimized to a large extent with reference to phronesis. In addition, the challenges associated with pluralistic teaching reported in the Green Flag empirics and in other studies of Swedish ESE indicate a need for support to practitioners that include tangible outlines of how bounding by design can be undertaken in legitimate ways.

In this regard, we note a correspondence between the justifications and O'Neill's typology of sources of legitimacy in deliberation on sustainability issues [43]. We suggest that this typology can be used both to support bounding by design and as a framework to examine this bounding critically. In O'Neill's work, the need to bound pluralism is expressed in terms of the impossibility and undesirability to design democratic processes in which the outside world is fully represented: "The congress of the world is not best represented by the world itself" (p. 485). This statement reveals how pluralism is not a useful democratic concept in its extreme form, as selective representation is necessary. The sources of legitimacy identified by $\mathrm{O}^{\prime}$ Neill concern the representation of certain people and of views that these people hold (he also discusses by whom these groups and views are represented, which in formal education typically means teachers and students, even though external actors can be present as well). The typology defines three sources of legitimacy:

1. Epistemic values. Here, knowledge, expertise and/or judgement legitimize that certain people or their views are represented. This source of legitimacy corresponds to justification 1 above, i.e., that views of experts conveyed through teachers and curricula are given precedence over opposing views by non-experts, thereby bounding pluralism.

2. Authority or democratic accountability. Here, authorization or political mandate legitimize that certain people and their views are represented. This source of legitimacy can be linked to justification 2 above, i.e., that objectives decided by elected bodies and expressed e.g., in the curriculum or the SDG's can be used to bound of pluralism. The authority of the teacher to steer the education also draws on this source of legitimacy.

3. Presence or shared identity. This source of legitimacy stems from direct presence of groups affected by an issue, or representation of these groups by others with whom they share aspects of identity. To the extent that a sustainability issue affects students and teachers, classroom deliberation in accordance with the pluralistic teaching tradition draws on this source of legitimacy. In terms of bounding of pluralism by design, it can be linked to justification 3, if a student council representing other students through shared identity decide on the scope and content of education. 
These sources of legitimacy can be combined in democratic decision making or educational settings, and the typology can be used to identify sources that are missing or should be strengthened (if possible- $\mathrm{O}^{\prime}$ Neill notes that representation of nonhumans and future generations can rely only on epistemic values, as presence or accountable representation is impossible). While different sources of legitimacy might be congruent and mutually enforcing, e.g., if objectives decided by elected political bodies reflect epistemic values such as scientific facts, tensions that correspond to those in our heuristic model can also be expected $[43,77]$. For example, different political objectives are frequently incompatible, and scientific facts might call for more radical societal change than what democratically accountable bodies stipulate. Hence, it is clear that that the typology does not offer a general recipe for the bounding of pluralism in ESE. Nonetheless, we argue that it can support practitioners to critically reflect on and make transparent and justifiable choices when designing ESE. Along with conceptualizations of the potential tensions between different ideals in ESE, as enabled in our heuristic model, it can assist in avoiding confusion and incoherence that follows if a rhetoric of pluralism conceals the normative and political implications inherent in its unavoidable bounding in a given ESE setting.

Author Contributions: Conceptualization, A.H. and M.W.; methodology, A.H. and M.W.; formal analysis, A.H. and M.W.; investigation, A.H.; data curation, A.H.; writing—original draft preparation, A.H.; writing-review and editing, M.W.; visualization, A.H.

Funding: This research is funded by the International Social Sciences Council as part of the T-learning Knowledge Network, grant number TKN 150314115141.

Conflicts of Interest: The authors declare no conflict of interest. The funders had no role in the design of the study; in the collection, analyses, or interpretation of data; in the writing of the manuscript, or in the decision to publish the results.

\section{References}

1. Lotz-Sisitka, H.; Wals, A.E.J.; Kronlid, D.; McGarry, D. Transformative, transgressive social learning: Rethinking higher education pedagogy in times of systemic global dysfunction. Curr. Opin. Environ. Sustain. 2015, 16, 73-80. [CrossRef]

2. Lucas, A.M. Environment and Environmental Education: Conceptual Issues and Curriculum Implications. Ph.D. Thesis, Ohio State University, Columbus, OH, USA, 1972.

3. Jickling, B.; Spork, H. Education for the Environment: A critique. Environ. Educ. Res. 1998, 4, 309-327. [CrossRef]

4. Fien, J. 'Education for the Environment: A critique'-An analysis. Environ. Educ. Res. 2000, 6, 179-192. [CrossRef]

5. Stables, A.; Scott, W. The Quest for Holism in Education for Sustainable Development. Environ. Educ. Res. 2002, 8, 53-60. [CrossRef]

6. Wals, A.E.J. Between knowing what is right and knowing that is it wrong to tell others what is right: On relativism, uncertainty and democracy in environmental and sustainability education. Environ. Educ. Res. 2010, 16, 143-151. [CrossRef]

7. Lambrechts, W.; Van Liedekerke, L.; Van Petegem, P. Higher education for sustainable development in Flanders: Balancing between normative and transformative approaches. Environ. Educ. Res. 2017, 4622, 1-17. [CrossRef]

8. Moore, J. Is Higher Education Ready for Transformative Learning? A Question Explored in the Study of Sustainability. J. Transform. Educ. 2005, 3, 76-91. [CrossRef]

9. Hesselink, F.; Van Kempen, P.P.; Wals, A.E.J. ESDebate: International Debate on Education for Sustainable Development; IUCN: Gland, Switzerland, 2000.

10. Wals, A.E.J. Review of Contexts and Structures for Education for Sustainable Development; UNESCO: Paris, France, 2009.

11. Kopnina, H. Sustainability in Environmental Education: Away from pluralism and towards solutions. Rebrae 2014, 295-313. 
12. Kopnina, H. Sustainability in environmental education: New strategic thinking. Environ. Dev. Sustain. 2015, 17, 987-1002. [CrossRef]

13. Öhman, J. Moral perspectives in selective traditions of environmental education-Conditions for environmental moral meaning-making and students' constitution as democratic citizens. In Learning to Change Our World? Swedish Research on Education \& Sustainable Development; Wickenberg, P., Ed.; Studentlitteratur: Lund, Sweden, 2004; pp. 33-57.

14. Englund, T. Deliberative communication: A pragmatist proposal. J. Curric. Stud. 2006, 38, 503-520. [CrossRef]

15. Rudsberg, K.; Öhman, J. Pluralism in practice-Experiences from Swedish evaluation, school development and research. Environ. Educ. Res. 2010, 16, 95-111. [CrossRef]

16. Englund, T. On moral education through deliberative communication. J. Curric. Stud. 2016, 48, 58-76. [CrossRef]

17. Fallace, T. Race, culture, and pluralism: The evolution of Dewey's vision for a democratic curriculum. J. Curric. Stud. 2012, 44, 13-35. [CrossRef]

18. Fritzell, C. Towards Deliberative Relationships between Pedagogic Theory and Practice. Nord. Stud. Educ. 2003, 23, 92-102.

19. Fritzén, L.; Gustafsson, B. Sustainable development in terms of democracy-An educational challenge for teacher education. In Learning to Change Our World? Swedish Research on Education \& Sustainable Development; Wickenberg, P., Axelsson, H., Fritzén, L., Helldén, G., Öhman, J., Eds.; Studentlitteratur: Lund, Sweden, 2004.

20. Englund, T.; Öhman, J.; Östman, L. Deliberative communication for sustainability? A Habermas-inspired pluralistic approach. In Sustainability and Security within Liberal Societies: Learning to Live with the Future; Gough, I.S., Stables, A., Eds.; Routledge: London, UK, 2008; pp. $29-48$.

21. Mezirow, J. Perspective Transformation. Adult Educ. Q. 1978, 28, 100-110. [CrossRef]

22. Mezirow, J. Transformative Dimensions in Adult Learning; Jossey-Bass: San Fransisco, CA, USA, 1991.

23. Jickling, B.; Wals, A.E.J. Globalization and environmental education: Looking beyond sustainable development. J. Curric. Stud. 2008, 40, 1-21. [CrossRef]

24. Lijmbach, S.; Van Arcken, M.M.; Van Koppen, C.S.A. 'Your View of Nature is Not Mine!': Learning about pluralism in the classroom. Environ. Educ. Res. 2002, 8, 121-135. [CrossRef]

25. Wildemeersch, D. Displacing concepts of social learning and democratic citizenship. In Civic Learning, Democratic Citizenship and the Public Sphere; Biesta, G., De Bie, M., Wildemeersch, D., Eds.; Springer Netherlands: Dordrecht, The Netherlands, 2013; pp. 15-28.

26. Læssøe, J. Education for sustainable development, participation and socio-cultural change. Environ. Educ. Res. 2010, 16, 39-57. [CrossRef]

27. Mogensen, F.; Schnack, K. The action competence approach and the "new" discourses of education for sustainable development, competence and quality criteria. Environ. Educ. Res. 2010, 16, 59-74. [CrossRef]

28. Van Poeck, K.; Vandenabeele, J. Learning from sustainable development: Education in the light of public issues. Environ. Educ. Res. 2012, 18, 541-552. [CrossRef]

29. Sund, L.; Öhman, J. On the need to repoliticise environmental and sustainability education: Rethinking the postpolitical consensus. Environ. Educ. Res. 2014, 20, 639-659. [CrossRef]

30. Van Poeck, K.; Östman, L. Creating space for 'the political' in environmental and sustainability education practice: A Political Move Analysis of educators' actions. Environ. Educ. Res. 2017, 24, 1406-1423. [CrossRef]

31. Håkansson, M.; Östman, L.; Van Poeck, K. The political tendency in environmental and sustainability education. Eur. Educ. Res. J. 2018, 17, 91-111. [CrossRef]

32. Håkansson, M.; Östman, L. The political dimension in ESE: The construction of a political moment model for analyzing bodily anchored political emotions in teaching and learning of the political dimension. Environ. Educ. Res. 2018. [CrossRef]

33. Mouffe, C. On the Political; Routledge: London, UK, 2005.

34. Orr, D. Ecological Literacy: Education and the Transition to a Postmodern World; State University of New York Press: Albany, NY, USA, 1992.

35. Wals, A.E.J. Social Learning: Towards a Sustainable World; Wagening Academic: Wagening, The Netherlands, 2007.

36. Sund, P. Experienced ESD-schoolteachers' teaching-An issue of complexity. Environ. Educ. Res. 2013, 21, 24-44. [CrossRef]

37. Öhman, J.; Öhman, M. Participatory approach in practice: An analysis of student discussions about climate change. Environ. Educ. Res. 2013, 19, 324-341. [CrossRef] 
38. Villanen, H. Teachers' reflections on an education for sustainable development project. Int. Res. Geogr. Environ. Educ. 2014, 23, 179-191. [CrossRef]

39. Olsson, D.; Gericke, N. The Adolescent Dip in Students' Sustainability Consciousness-Implications for Education for Sustainable Development. J. Environ. Educ. 2016, 47, 35-51. [CrossRef]

40. Læssøe, J. Participation and sustainable development: The post-ecologist transformation of citizen involvement in Denmark. Environ. Polit. 2007, 16, 231-250. [CrossRef]

41. Sunstein, C.R.; Thaler, R.H.; Duchen, C. Libertarian Paternalism is Not an Oxymoron. Univ. Chic. Law Rev. 2003, 70, 1159-1202. [CrossRef]

42. Thaler, R.H.; Sunstein, C.R. Nudge; Yale University Press: New Haven, CT, USA, 2008.

43. O'Neill, J. Representing people, representing nature, representing the world. Environ. Plan. C Gov. Policy 2001, 19, 483-500. [CrossRef]

44. Grön Flagg-Hållbar Utveckling för Barn Och Unga. Available online: https://www.hsr.se/sites/default/ files/gronflagg-broschyr.pdf (accessed on 18 December 2018).

45. Jidesjö, A. Preparing for Nagoya: The Implementation of Education for Sustainable Development (ESD) in Sweden; Report Written for the Swedish International Centre of Education for Sustainabile Development: Visby, Sweden, 2014.

46. Pauw, J.; Gericke, N.; Olsson, D.; Berglund, T. The Effectiveness of Education for Sustainable Development. Sustainability 2015, 7, 15693-15717. [CrossRef]

47. Schön, D.A.; Rein, M. Frame Reflection: Toward the Resolution of Intractable Policy Controversies; Basic Books: New York, NY, USA, 1994.

48. Hajer, M.A. Deliberative Policy Analysis: Understanding Governance in the Network Society; Cambridge University Press: Cambridge, UK, 2003.

49. Dekker, R. Frame ambiguity in policy controversies: Critical frame analysis of migrant integration policies in Antwerp and Rotterdam. Crit. Policy Stud. 2017, 11, 127-145. [CrossRef]

50. Östman, L.O. Socialisation och Mening: No-Utbildning som Politiskt och Miljömoraliskt Problem. Ph.D. Thesis, Uppsala University, Uppsala, Sweden, 1995.

51. Östman, L.; Öhman, J. A transactional approach to learning. Presented at the John Dewey Society Annual Meeting, Denver, CO, USA, 30 April-4 May 2010.

52. Sandell, K.; Öhman, J.; Östman, L. Education for Sustainable Development: Nature, School and Democracy, 2nd ed.; Studentlitteratur: Lund, Sweden, 2005.

53. Biesta, G. Good Education in an Age of Measurement: On the Need to Reconnect with the Question of Purpose in Education. Educ. Assess. Eval. Account. 2009, 21, 33-46. [CrossRef]

54. O'Sullivan, E. Transformative Learning: Educational Vision for the 21st Century; Zed Books: London, UK, 1999.

55. Torbjörnsson, T. Solidaritet och Utbildning för Hållbar Utveckling. En Studie av Förväntningar på och Förutsättningar för Miljömoraliskt Lärande i den Svenska Gymnasieskolan. Ph.D. Thesis, Uppsala University, Uppsala, Sweden, 2014.

56. Kuypers, J.A. Rhetorical Criticism: Perspectives in Action; Lexington Books: Lanham, MD, USA, 2009.

57. Vår Filosofi-Handlingskraft \& Hållbar Utveckling i Skolan. Available online: www.hsr.se/sites/default/ files/omhallbarutveckling.pdf (accessed on 18 December 2018).

58. Plast i Fisken? Available online: https://www.hsr.se/exempelsamling/plast-i-fisken (accessed on 18 December 2018).

59. Framtidsfrågor i Klassrummet. Klimat \& Energi. En Didaktisk Vägledning för åk 4-9. Available online: https:/ / www.hsr.se/sites/default/files/didaktiskhandledning.pdf (accessed on 18 December 2018).

60. Kopnina, H. Education for Sustainable Development (ESD): The turn away from "environment" in environmental education? Environ. Educ. Res. 2012, 18, 699-717. [CrossRef]

61. Block, T.; Goeminne, G.; Van Poeck, K. Balancing the urgency and wickedness of sustainability challenges: Three maxims for post-normal education. Environ. Educ. Res. 2018, 24, 1424-1439. [CrossRef]

62. Svennbeck, M. Omsorg om Naturen: Om NO-Utbildningens Selektiva Traditioner med Fokus på Miljöfostran och Genus. Ph.D. Thesis, Uppsala University, Uppsala, Sweden, 2003.

63. Molin, L. Rum, Frirum och Moral: En Studie av Skolgeografins Innehållsval. Ph.D. Thesis, Uppsala University, Uppsala, Sweden, 2006.

64. Gustafsson, B. Undersökningar av Sociovetenskapliga Samtal i Naturvetenskaplig Utbildning. Ph.D. Thesis, Linnaeus University, Växjö/Kalmar, Sweden, 2010. 
65. Hedefalk, M. Förskola för Hållbar Utveckling: Förutsättningar för Barns Utveckling av Handlingskompetens för Hållbar Utveckling. Ph.D. Thesis, Uppsala University, Uppsala, Sweden, 2014.

66. Håkansson, M.; Kronlid, D.O.O.; Östman, L. Searching for the political dimension in education for sustainable development: Socially critical, social learning and radical democratic approaches. Environ. Educ. Res. 2017, 4622, 1-27. [CrossRef]

67. Kronlid, D.O. Skolans Värdegrund 2.0. Etik för en Osäker Tid; Natur \& Kultur: Stockholm, Sweden, 2017.

68. Öhman, J. Pluralism and criticism in environmental education and education for sustainable development: A practical understanding. Environ. Educ. Res. 2006, 12, 149-163. [CrossRef]

69. Habermas, J. Between Naturalism and Religion: Philosophical Essays; Wiley: New York, NY, USA, 2008.

70. Fraser, N. Rethinking the public sphere: A contribution to the critique of actual existing democracy. In Habermas and the Public Sphere; Calhoun, C., Ed.; Cambridge University Press: Cambridge, UK, 1993; pp. 109-142.

71. Sund, P.; Lysgaard, J.G. Reclaim "education" in environmental and sustainability education research. Sustainability 2013, 5, 1598-1616. [CrossRef]

72. Dewey, J. Democracy and Education: An Introduction to the Philosophy of Education; Macmillan: New York, NY, USA, 1916.

73. Mougan, C.M.; Nussbaum, J. Dewey and Education for Democratic Citizenship. Pragmatism Today 2013, 4, 83-90.

74. Sunstein, C. The Ethics of Nudging. Yale J. Regul. Artic. 2015, 32, 413-450. [CrossRef]

75. Pedwell, C. Habit and the Politics of Social Change: A Comparison of Nudge Theory and Pragmatist Philosophy. Body Soc. 2017, 23, 59-94. [CrossRef]

76. Kelly, T.E. Discussing controversial issues: Four perspectives on the teacher's role. Theory Res. Soc. Educ. 1986, 14, 113-138. [CrossRef]

77. Connelly, S.; Richardson, T.; Miles, T. Situated legitimacy: Deliberative arenas and the new rural governance. J. Rural Stud. 2006, 22, 267-277. [CrossRef]

(C) 2019 by the authors. Licensee MDPI, Basel, Switzerland. This article is an open access article distributed under the terms and conditions of the Creative Commons Attribution (CC BY) license (http:/ / creativecommons.org/licenses/by/4.0/). 